\title{
Identifying Factors Influencing Rice Production and Consumption in Indonesia
}

\author{
Abdul Bashir ${ }^{1}$, Saadah Yuliana ${ }^{2}$ \\ 1, 2 Department of Development Economics, \\ Faculty of Economics, Universitas Sriwijaya, Indonesia \\ Corresponding Author: abd.bashir@unsri.ac.id, saadahyuliana@fe.unsri.ac.id
}

Recieved: March 2018 | Revised: July 2018 | Accepted: November 2018

\begin{abstract}
This study analyzes factors affecting rice production and consumption in Indonesia from 1990-2014, the data source is from Central Bureau of Statistics (BPS). The method used is model of multiple linear regression equation with ordinary least square estimator (OLS). Our findings indicate that rice production can be affected by human capital, labor, wages, wetland, urban population, and rice prices; on the other side, technology has no effect on rice production. Other findings on the rice consumption model were influenced by human capital, per capita income, population, and consumption the previous year, and on the other side, rice prices have no affect rice consumption in Indonesia. It's an important note for the government in making the right program policies such as the development of irrigation systems and better water management.
\end{abstract}

Keywords: consumption, human capital, rice price, rice production, technology.

JEL classification: Q1, Q11, Q18.

How to Cite: Bashir, A., \& Yuliana, S. (2018). Identifying factors influencing rice production and consumption in Indonesia. Jurnal Ekonomi Pembangunan: Kajian Masalah Ekonomi dan Pembangunan, 19(2). doi:https://doi.org/10.23917/jep.v19i2.5939

DOI: https://doi.org/10.23917/jep.v19i2.5939

\section{Introduction}

Rice food is the most basic human need, so the availability of rice for the community must always be guaranteed (Clapp, 2017; Timmer, 2013). In addition, rice is one of the most important staple foods in the world (Fairhurst \& Dobermann, 2002). This statement is particularly applicable in Asia, where rice is the staple food for the majority of the population at the middle to low level. The Asian continent is also home to farmers producing about $90 \%$ of the world's total rice production (Clarete, Adriano, \& Esteban, 2013).
Increasing rice food security is a key development priority, as rice food is the most basic need for humans (Clarete et al., 2013; FAO, 2009). Increasing population growth requires the availability of food from agricultural products sufficient to strengthen food security in a region (Clapp, 2017), this is because rice food security has a central position in increasing productivity and improving the quality of life of citizens.

As an illustration of data published by FAO in 2014, there are five largest rice producing countries in the world namely China, India, Indonesia, Bangladesh and Vietnam, and the 
share of rice production to the world in 2014 respectively $28.06 \%, 20,97 \%, 9.52 \%, 7.07 \%$ and $6.06 \%$ respectively (Table 1 ). Although the five countries are the largest rice producers in the world, only $5 \%$ of global rice production is traded on international markets (Jha, Kubo, \& Ramaswami, 2016, implying that rice prices are vulnerable to changes in supply and demand.

Furthermore, rice supply in the international market only comes from three rice exporting countries, namely Thailand, India and Viet Nam (Jha et al., 2016). The sudden change in the rice exporter country's trade policy could lead to stockpiling and speculation by rice importing countries, it is likely to raise the price of rice significantly, and with dangerous risks, as it will have an impact on increasing poverty in Asian countries (Grochowska \& Kosior, 2013; Inoue, Okae, \& Akashi, 2015; Milovanovic \& Smutka, 2017).

The phenomenon occurred in 2008 when the price of rice increased significantly and caused the poverty rate in the Asian continent to increase. In response to the situation, various countries in the Asian continent have signed the ASEAN Plus Three Emergency Rice Reserve (APTERR) agreement stipulating that a total of 0.78 million tons of rice will be held jointly by participating countries, namely ASEAN countries plus China,
Japan and South Korea (ASEAN, 2008), to be used in response to the volatility of international rice prices or when required due to natural disasters or other humanitarian assistance (Clarete et al., 2013). The most of rice supply significant contribution in this agreement comes from China, Japan and South Korea.

Of the five countries, Indonesia is one of the agrarian countries that are able to produce rice in large quantities. Yet almost every year, rice imports are still being used for food stocks and supply some of the areas lacking, in addition to keeping rice prices stable at the regional level. One other cause related to the fulfillment of rice needs (rice consumption) in Indonesia is the total population which every year is growing, in 2014 per capita rice consumption of $97 \mathrm{~kg}$ per year, and the average growth of per capita rice consumption increased by $0.80 \%$ during $1990-2014$. The slower growth of rice consumption one of them is caused by the government policy currently to increase rice production, and reduce rice consumption by $1.5 \%$ per year, with the intention to accelerate food diversification consumption and or to support rice import policy (Wardis, 2014). On the other side, rice consumption can also be influenced by per capita income, population, rice stock, and subsidy from the government (Azwardi, et al., 2016; Nuryanti, 2005).

Table 1. The five biggest rice producing countries in the world

\begin{tabular}{rlrr}
\hline Ranking & Countries & Production volume (ton) & Share to world (\%) \\
\hline 1 & China & 208.100 .000 & 28,06 \\
2 & India & 155.500 .000 & 20,97 \\
3 & Indonesia & 70.600 .000 & 9,52 \\
4 & Bangladesh & 52.400 .000 & 7,07 \\
5 & Viet Nam & 44.900 .000 & 6,06 \\
Total of five countries & $\mathbf{5 3 1 . 5 0 0 . 0 0 0}$ & $\mathbf{7 1 , 6 8}$ \\
\multicolumn{2}{l}{ Total of world } & $\mathbf{7 4 1 . 5 0 0 . 0 0 0}$ & $\mathbf{1 0 0 , 0 0}$ \\
\hline
\end{tabular}

Source: FAOSTAT Data, December 2014 
Table 2. Data and data source

\begin{tabular}{llcc}
\hline Variable & \multicolumn{1}{c}{ Description } & Unit & Source \\
\hline QR & Rice production & tons & Indonesia Statistics (BPS) \\
CRP & Rice consumption per capita & $\mathrm{kg}$ & Indonesia Statistics (BPS) \\
HC & Human capital index (Barro \& Lee, 2013) & index & Federal Reserve Bank (FRED) \\
GDPC & GDP per capita & million & Indonesia Statistics (BPS) \\
POP & Population & people & Indonesia Statistics (BPS) \\
URB & Urban population & people & Indonesia Statistics (BPS) \\
PRR & Rice price & rupiah & Indonesia Statistics (BPS) \\
L & Labor & people & Indonesia Statistics (BPS) \\
LA & Wetland area & hectare & Indonesia Statistics (BPS) \\
WF & Wages & rupiah & Indonesia Statistics (BPS) \\
T & Technology (ratio QR to wetland) & ratio & Indonesia Statistics (BPS) \\
\hline
\end{tabular}

On the production side, growth and development of rice production has been entirely dependent on increasing yields. To meet demand, rice production can be increased either by increasing the area of rice cultivation or by increasing the efficiency of existing resources allocated for rice production (Koirala, Mishra, \& Mohanty, 2013). Increased production can be arranged in two ways; (i) a shift in production limits, and (ii) by developing and promoting technology to increase production. in addition, increased rice production can also contribute to reducing poverty, especially in rural areas (Bordey, 2010; Dawe, 2000). Increased production can also help increase income and food security in most populations in Indonesia, especially in populations whose main livelihoods are rice farmers. In addition, rice production may also be affected by factors such as land area, rice price, labor, wage rate, and use of modern technology (Azwardi et al., 2016; Koirala et al., 2013).

Meanwhile, the economic development in the future will increase of the human capital, while in some the literature assumes that human capital can to changes production pattern and consumption because the development of human capital investment in the developing countries will provide an economic return by increasing both the employment rate and labor income (Huffman, 2000; and Huffman \& Orazem, 2007). On the other side, changes of economic development in the future will to change the economic structure, which will also cause to changes in workforce structure, of course, the changes that occur will cause urbanization in the future which will also impact to agriculture production and food production (Satterthwaite, McGranahan, \& Tacoli, 2010).

Several previous studies that also used macro assumptions, such as studies that have conducted by Azwardi et al. (2016); Malian, Sudi, \& Mewa (2004); and Nuryanti (2005) indicated that previous study has focused on factors that influence rice production and consumption such as rice prices, total labor, land area, economic growth, rice consumption, productivity as technology, population, wage, and other factors. Therefore, in this study, to facilitate the modeling build, we used variable of human capital and urbanization are assumed to change the quantity of rice production and consumption. The objective of this study is to identify factors that influence rice production and consumption, especially to see how the influence of human capital and urbanization on rice production and consumption in Indonesia.

\section{Research Methods}

The focus of this study is the identifying determinants of rice production and consumption 
in Indonesia from 1990-2014, the data used is secondary obtained from the Central Bureau of Statistics (BPS) in various editions.

The dependent variables used by rice production (QR) and rice consumption per capita (CRP), while those used as independent variables include: per capita income (GDPC); human capital (HC); population (POP); urban population (URB); labor (L), wage level (WF); rice price (PRR); wetland area (LA); and agricultural technology (T). The method of analysis using the quantitative approach with the multiple linear regression models in estimation with ordinary least square (OLS).

Before estimating the linear regression model using time series, it is necessary to test whether the variable data used is stationary or not stationary, test the data stationary with using unit root test with Augmented Dickey-Fuller Test criteria (ADF-Test) which was introduced by Dickey \& Fuller (1979), and another similar test of Phillips-Perron (PP) Test introduced by Phillips \& Perron (1988). Further testing was re-developed by Levin, Lin, \& Chu (2002) hereinafter referred to LLC, and by Im, Pesaran, $\&$ Shin (2005) hereinafter referred to as IPS. The equation of unit root test of LLC by considering the criteria of $\mathrm{ADF}$ as follows:

$\Delta \mathrm{Y}_{\mathrm{t}}=\beta_{1}+\beta_{2} \mathrm{t}+\delta \mathrm{Y}_{\mathrm{t}-1}+\sum_{\mathrm{i}=1}^{\mathrm{m}} \alpha_{\mathrm{i}} \Delta \mathrm{Y}_{\mathrm{t}-\mathrm{i}}+\mathrm{u}_{\mathrm{t}}$

where: $\mathrm{Y}_{\mathrm{t}}$ is the vector of the main endogenous variables in the study of rice production and consumption.

Unit root test of LLC assumes that the accuracy of $B_{1}$ parameter is identical across the passage (i.e, $B_{1}=B$ for all $i$ ), whereas the order of lag $B_{1}$ can freely vary. This procedure tests the null hypothesis $B_{1}=0$ for all $i$ against the alternative hypothesis $B_{1}<0$ for all $i$. The rejection of the null hypothesis shows the possibility of continuing the process of integration of time series data and vice versa.

While the IPS unit root test, which is also based on equation (1), is different from the LLC unit root test, assuming $\mathrm{Bi}$ to be heterogeneous across the passages. The IPS unit root test tests the null hypothesis of null hypothesis $\beta_{i}=0$ against alternative hypothesis $B_{i}<0$, $\left(i=1, \ldots, N_{1}\right) ; B_{i}=0$, $\left(\mathrm{i}=\mathrm{N}_{1}, \ldots, \mathrm{N}\right)$ for all $i$. Acceptance of alternative hypotheses enables individual series to be integrated. The root test of the LLC and IPS units can be estimated on the data of level and for the first difference in the form of natural logarithms.

The next step is after testing the model of regression equation transformed into natural logarithm using OLS estimator, then testing the violation of classical assumption in the model, as for diagnostic test on the model such as testing of data normality, autocorrelation, multicollinearity, and heteroscedasticity (Gujarati, 2004). This study uses two models, (i) regression equation model of rice production and (ii) rice consumption per capita model. The model of regression equation can be presented as follows:

\section{a. Model of rice production}

The specification of the rice production model in this study refers to the production function of Cobb-Douglas (Felipe \& Adams, 2005), and several other studies such as Antle (1984); Azwardi et al. (2016); Kea, Li, \& Pich (2016); Koirala et al. (2013); Shaikh \& Ahmed (2016).

$Q_{t}=\beta_{0} K^{\beta_{1}} L^{\beta_{2}} Z^{\beta_{n}} \mu^{u}$

Equation (2) above is adapted from the production function of cobb-Douglas which is a non-linear model form, where Qt is the production of rice; $\mathrm{K}$ is human capital; $\mathrm{L}$ is labor; and $\mathrm{Z}$ is another variable that affects the rice production. Whereas $B_{0}, B_{1}, B_{2} \ldots, B_{n}$ is the parameter coefficient; and $u$ is the error rate (error term). Equation (3) is a function of rice production.

$$
\mathrm{QR}_{t}=\mathrm{f}\left(\mathrm{HC}_{\mathrm{t}}, \mathrm{L}_{\mathrm{t}}, \mathrm{LA}_{\mathrm{t}}, \mathrm{WF}_{\mathrm{t}}, \mathrm{PRR}_{\mathrm{t}}, \mathrm{URB}_{\mathrm{t}}, \mathrm{T}_{\mathrm{t}}\right)
$$

Equations (2) and (3) are transformed into a natural logarithm, while the linear regression equation (4) model is presented as follows: 
$\ln Q R^{t}=B_{0}+B_{1} \ln \mathrm{C}_{\mathrm{t}}+B_{2} \operatorname{lnL}_{\mathrm{t}}+B_{3} \operatorname{lnLA_{\mathrm {t}}}+B_{4} \ln \mathrm{WF}_{\mathrm{t}}$ $+B_{5} \ln \mathrm{PRR}_{\mathrm{t}}+B_{6} \ln \mathrm{nRB}_{\mathrm{t}}+B_{7} \ln \mathrm{T}_{\mathrm{t}}+\mu_{1 \mathrm{t}}$

where: $\mathrm{QR}$ is the rice production; $\mathrm{L}$ is labor; $\mathrm{LA}$ is the wetland area; WF is the wage rate; $\mathrm{PRR}$ is the rice price; $\mathrm{HC}$ is human capital; $\mathrm{URB}$ is the village population; and agricultural technology $(\mathrm{T})$.

\section{b. Model of rice consumption}

The model specification of rice consumption in this study refers to a study conducted by Azwardi et al. (2016); Fakayode et al. (2010); Micheal (1972); and Wohlgenant \& Hahn (1982).

$\mathrm{Y}_{\mathrm{t}}=\mathrm{a}_{\mathrm{o}} \mathrm{X}^{\mathrm{a} 1} \mathrm{Z}^{\mathrm{an}} \varepsilon^{\mathrm{u}}$

where: $\mathrm{Y}$ is the demand for rice; $\mathrm{X}$ is the price of rice; $\mathrm{Z}$ is another variable affecting rice demand; $\mathrm{a}_{0}, \mathrm{a}_{1}, \ldots, \mathrm{a}_{\mathrm{n}}$ is the parameter coefficient; and $u$ is the error rate (error term). The above model is a non-linear model. Simply can be formed with the function as presented in equation (6) at this follows:

$$
\mathrm{CRP}_{\mathrm{t}}=\mathrm{f}\left(\mathrm{PRR}_{\mathrm{t}}, \mathrm{GDPC}_{\mathrm{t}}, \mathrm{POP}_{\mathrm{t}}, \mathrm{HC}_{\mathrm{t}}, \mathrm{CRP}_{\mathrm{t}-\mathrm{t}}\right)
$$

Equation (6) above is a function of rice consumption per capita (CRP) that is influenced by other factors, such as rice price (PRR); per capita income (GDPC); population (POP); human capital (HC); lag of rice consumption per capita $\left(\mathrm{CRP}_{\mathrm{t}-1}\right)$. To estimate the model, the equations (5) and (6) are transformed into natural logarithms, while the linear regression equation model is presented in equation (7) below:

$$
\ln \mathrm{CRP}_{\mathrm{t}}=\mathrm{a}_{0}+\mathrm{a}_{1} \ln \mathrm{PRR}_{\mathrm{t}}+\mathrm{a}_{2} \operatorname{lnGDPC}_{\mathrm{t}}+\mathrm{a}_{3} \ln \mathrm{POP}_{\mathrm{t}}
$$$$
+\mathrm{a}_{4} \ln \mathrm{HC}_{\mathrm{t}}+\mathrm{a}_{5} \ln \mathrm{CRP}_{\mathrm{t}-1}+\varepsilon_{2 \mathrm{t}}
$$

Equation (7) shows the transformed model to be natural logarithms. One of the advantages of the logarithm model is the slope coefficient $a_{0}, a_{1}, \ldots, a_{n}$ in the logarithmic model, since the slope coefficient value is actually a measure of the elasticity of $\mathrm{Y}$ against $\mathrm{X}$, in other words, slope coefficient is the rate of change in variable $\mathrm{Y}$ (percent), if there is a change in variable $\mathrm{X}, \mathrm{Z}$ (percent).

\section{Result and Discussion}

Economic development in Indonesia is inseparable from the role of the agricultural sector. As an agricultural country, approximately 40\% of Indonesians depend on agricultural products. The agricultural sector has a very big role in terms of providing employment, food providers, foreign exchange contributors through exports and so on. Several studies have found that the agricultural sector is the engine of growth both in terms of supply of raw materials, food, and as input power for products produced by other sectors (Apostolidou, Kontogeorgos et al., 2014; Tiffin \& Irz, 2006). Naturally, economic growth must be supported by the development of a strong agricultural sector both in terms of supply and demand.

The role of the government at this time is very important because to avoid a crisis in the agricultural sector, the government must intervene with agricultural policy (agricultural policy). Government policies related to domestic rice production include price policy and input and output trade, which in principle aims to strengthen or enhance the competitiveness of the commodities concerned in the domestic market (Azwardi et al., 2016).

Indonesia ranks third after China and India are able to produce large quantities of rice (Table 1). On the other hand, rice imports are still carried out by the government for food stocks to supply some of the areas lacking. In addition, rice imports are also expected to maintain rice price stability. On the other hand, rice consumption is also quite high, because rice is the main food in Indonesia, the high consumption of rice is also caused by a large number of populations. 


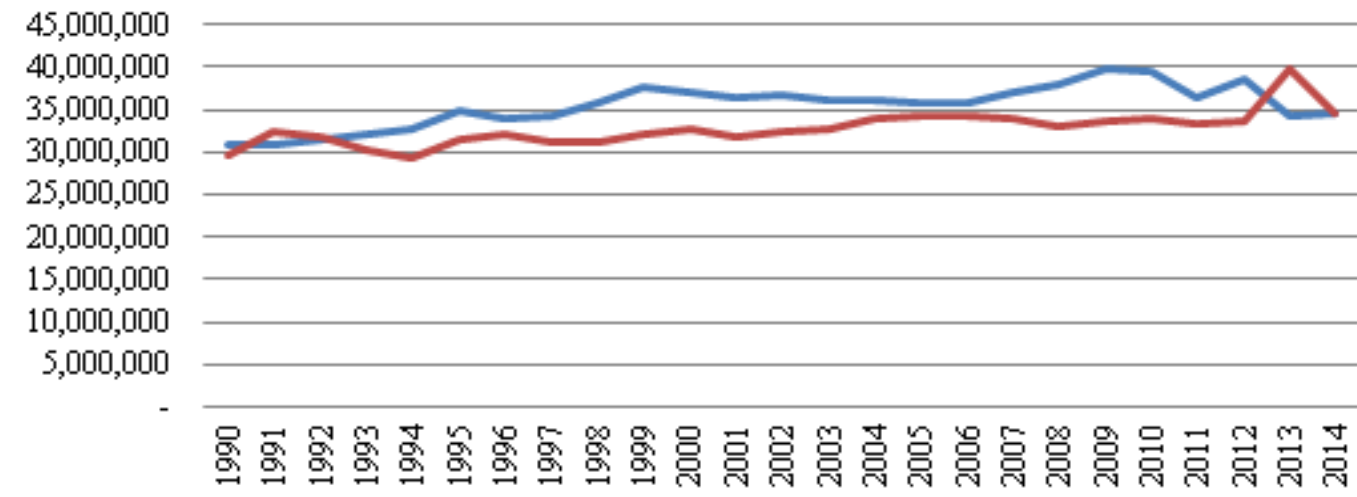

production (tons) Consumption (tons)

Source: BPS, Statistics Indonesia, various editions (processed)

Figure 1. The trend of rice production and consumption in Indonesia, 1990-2014

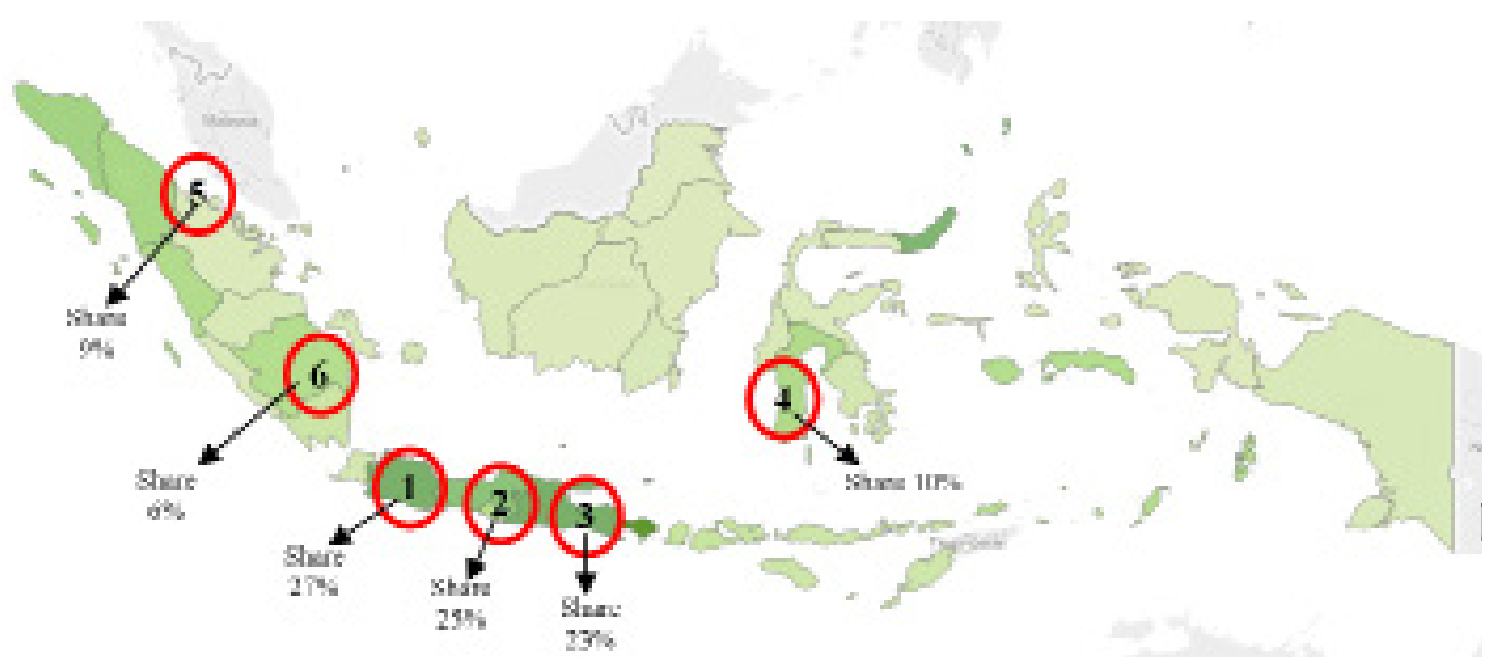

Note: The map of the location of the region as the largest producer of rice production in Indonesia, No 1 . West Java province; No 2. East Java; No. 3 Central Java; No. 4 South Sulawesi; No. 5 North Sumatra; and No. 6

South Sumatra. The rating is determined based on contribution to total rice production in Indonesia. Source: BPS, Statistics Indonesia (Authors calculation)

Figure 2. The Map of market share of the six biggest provinces of rice production

Generally, the development of rice production and consumption in Indonesia has indicated a positive trend, although the amount of national rice consumption has decreased in 2014 compared to 2013 , the condition is inversely proportional to decreased production in 2013 (Figure 1), the average grows almost about $1.75 \%$ and $1.78 \%$ respectively. In 2014 rice production recovers, with the government's policy to eliminate energy subsidies and increase non-energy subsidies (Azwardi et al., 2016). In addition, the development of rice production can also be influenced by many factors, such as land area, the number of labor, and the more modern technology.

Rice production in Indonesia is dominated by small farmers, not by large companies owned by private or state. These smallholders contribute about $90 \%$ of the total rice production in Indonesia. In addition, the average land area in each farmer's work is less than 0.8 hectares. There are six regions as rice production centers, such as Central Java, South Sumatera, North Sumatera, East Java, West Java, and South Sulawesi. 
Rice production in Indonesia is quite large compared to other countries in the world, but when compared with the population is still very little, almost every year rice production in Indonesia has a deficit. This indicates that the productivity of farmers in Indonesia is still very low. Many factors that cause such low productivity such as the grain price and low wages, and wetland area that have not been productive. In addition, rice production can also be caused from other factors such as seeds used and dry land structures.

In Figure 2 above, there are 6 (six) provinces as the main centers of rice production in Indonesia, the average contribution of six regions to total rice production in the period 1990-2014, among others, West Java with a contribution of $27 \%$ East Java (25\%), Central Java (23\%), South Sulawesi (10\%), while in Sumatera Island, North Sumatera and South Sumatra with $9 \%$ and $6 \%$ contribution of rice production respectively. But the production is not proportional to the population's demand for rice. This needs to be a serious concern for the government, as rice needs in Indonesia continue to increase, but on the other hand rice production is growing slower than consumption. Government policy in Indonesia is currently focused only on the production side. On the other hand, the price of grain at the farm level is low. Table 2 shows the unit root test results using the $\mathrm{ADF}$ test after the first-order differentiation process.

The results of the ADF test compared with the critical value of McKinnon. If the ADF $t$-statistic value is less than the critical value of McKinnon, then the data is not stationary, and vice versa if the $\mathrm{ADF}$ t-statistic value is greater than the critical value of McKinnon, then the data is stationary. Unit root test at first difference result indicated that all variables in this study were stationary at $1 \%$ significance level (Table 3 ). This means that all variables in this study can be used for time series analysis and predefined model equations.

Furthermore, the diagnostic test of multiple regression equation models for rice production (model-1) and consumption (model-2), Table 3 shows the results of autocorrelation test based on Jarque-Bera criteria indicates that the probability of Jarque-Bera (JB) $>0,05$, it can be concluded that the residual is normally distributed (Table 4). In addition, heteroscedasticity test with BreuschPagan criteria showed that the probability of $\mathrm{X}^{2}>0.05$, it can be concluded that there are no symptoms of heteroscedasticity in the model. The next assumption test is autocorrelation with the Breusch-Godfrey criterion indicating that there are no autocorrelation in the model (Table 4).

Table 3. Result of unit root test: at level \& first differences

\begin{tabular}{|c|c|c|c|c|c|}
\hline \multirow{2}{*}{ Variable } & \multirow{2}{*}{ t-statistics ADF } & \multicolumn{3}{|c|}{ ADF McKinnon Critical Value } & \multirow{2}{*}{ Unit Root Test } \\
\hline & & $1 \%$ & $5 \%$ & $10 \%$ & \\
\hline $\mathrm{D}(\operatorname{lncrp})$ & -4.475353 & -3.752946 & -2.998064 & -2.638752 & $* *$ stationary \\
\hline $\mathrm{D}($ lngdpc $)$ & -7.012405 & -3.752946 & -2.998064 & -2.638752 & $* *$ stationary \\
\hline $\ln (\mathrm{hc})$ & -12.51526 & -3.737853 & -2.991878 & -2.635542 & *stationary \\
\hline $\ln (\mathrm{la})$ & -4.898977 & -3.737853 & -2.991878 & -2.635542 & *stationary \\
\hline $\ln ($ pop$)$ & -8.119575 & -3.737853 & -2.991878 & -2.635542 & *stationary \\
\hline $\mathrm{D}(\operatorname{lnprr})$ & -5.378061 & -3.788030 & -3.012363 & -2.646119 & $* *$ stationary \\
\hline $\mathrm{D}(\operatorname{lnqr})$ & -4.061621 & -3.752946 & -2.998064 & -2.638752 & $* *$ stationary \\
\hline $\mathrm{D}$ (lnrur) & -4.537528 & -3.769597 & -3.004861 & -2.642242 & $* *$ stationary \\
\hline $\mathrm{D}(\operatorname{lnwf})$ & -4.440279 & -3.752946 & -2.998064 & -2.638752 & ${ }^{* *}$ stationary \\
\hline
\end{tabular}

Source: Authors calculation 
Table 4. Result of model diagnostic tests

\begin{tabular}{lllll}
\hline \multicolumn{1}{c}{ Diagnostic } & \multicolumn{1}{c}{ Test } & Model-1 & Model-2 & Note \\
\hline Normality & Jarque-Bera & $0.6001>0.05$ & $0.9188>0.05$ & Reject $\mathrm{H}_{\mathrm{o}}$ \\
Heteroscedasticity & Breusch-Pagan & $0.6124>0,05$ & $0.5244>0.05$ & Accept $\mathrm{H}_{\mathrm{o}}$ \\
Autocorrelation & Breusch-Godfrey & $0.0664>0.05$ & $0.1191>0.05$ & Accept $\mathrm{H}_{\mathrm{o}}$ \\
\hline \multicolumn{2}{r}{ Source: Authors calculation }
\end{tabular}

Table 5. Examination of correlation matrix of rice production model

\begin{tabular}{ccccccc}
\hline & $\operatorname{lnl}$ & $\operatorname{lnwf}$ & $\operatorname{lnla}$ & $\operatorname{lnhc}$ & $\operatorname{lnprr}$ & $\operatorname{lnurb}$ \\
\hline lnwf & 0.498 & - & - & - & - & - \\
lnla & 0.204 & 0.139 & - & - & - & - \\
$\operatorname{lnhc}$ & 0.455 & 0.497 & 0.132 & - & - & - \\
lnprr & 0.472 & 0.481 & 0.101 & 0.581 & - & - \\
lnurb & 0.480 & 0.678 & 0.097 & 0.675 & 0.685 & - \\
lntec & 0.068 & 0.514 & 0.140 & 0.550 & 0.613 & 0.583 \\
\hline
\end{tabular}

Table 6. Examination of correlation matrix of rice consumption model

\begin{tabular}{cccc}
\hline & lnprr & lngdpc & $\operatorname{lnhc}$ \\
\hline lngdpc & 0.584 & - & - \\
$\operatorname{lnh} c$ & 0.481 & 0.692 & - \\
$\operatorname{lnpop}$ & 0.585 & 0.594 & 0.697 \\
\hline \multicolumn{4}{c}{ Source: Authors calculation }
\end{tabular}

Table 5 presents the results of correlation test between independent variables indicating that all coefficient values are still within the tolerance limit that is below 0.80 (Gujarati, 2004), which means the relationship between independent variables is not strong enough, so it can be said that there is no symptom of multicollinearity in rice production model. Furthermore, the multicollinearity test using the correlation matrix for the rice consumption model shows that the relationship between independent variables does not have a strong relationship. The correlation coefficient between these variables is still below the value of 0.80 , so it can be concluded that there is no symptom of multicollinearity in the rice consumption model (Table 6).

\subsection{Analysis of rice production model}

In Table 7, we present the model estimation of rice production and consumption using OLS estimator. In the estimation of the rice production model (model-1) it is seen that human capital affects rice production significantly at $1 \%$ level, the sign of the coefficient shown is positive, it means that as the level of individual education (human capital) improvement of individual productivity, meaning that education level in this case is very important in pushing rice production more efficient, the results are also in line with the studies undertaken by Chen, Huffman, \& Rozelle (2003) dan Ekou (2015). Of course the use of inputs used by farmers is generated from the development of increasingly modern technology. Furthermore, rice production is also significantly influenced by the number of labor, wages, rice field area, urban population, and rice price, the signs of each coefficient of the indicated variables are positive. These five factors have a coefficient of each $0.116 ; 0.615 ; 0.237 ; 0.670$; and 0.101 . However, technological factors have no effect on rice production. 
Table 7. Result of model estimation

\begin{tabular}{|c|c|c|c|}
\hline Variable & Description & Model-1 & Model-2 \\
\hline $\mathrm{c}$ & Constant & $\begin{array}{c}147.4499 * * * \\
(39.16265)\end{array}$ & $\begin{array}{c}118.9975 * * * \\
(37.52190)\end{array}$ \\
\hline $\operatorname{lnhc}$ & Human capital & $\begin{array}{c}0.215948 * * * \\
(0.064375)\end{array}$ & $\begin{array}{c}-0.762767 * * * \\
(0.084305)\end{array}$ \\
\hline $\operatorname{lnl}$ & labor of agriculture sector & $\begin{array}{c}0.115963 * * \\
(0.090176)\end{array}$ & \\
\hline $\operatorname{lnwf}$ & Wage of agriculture sector & $\begin{array}{c}0.614589 * * \\
(0.121971)\end{array}$ & \\
\hline $\operatorname{lnla}$ & Wetland area & $\begin{array}{l}0.237636^{*} \\
(0.124356)\end{array}$ & \\
\hline lnrur & Urban population & $\begin{array}{c}-0.670057^{* *} \\
(0.209510)\end{array}$ & \\
\hline $\ln t$ & Technology & $\begin{array}{c}0.084419 \\
(0.045996)\end{array}$ & \\
\hline $\operatorname{lnprr}$ & Price of rice & $\begin{array}{c}0.101692^{* *} \\
(0.048571)\end{array}$ & $\begin{array}{c}0.016191 \\
(0.035325)\end{array}$ \\
\hline $\operatorname{lngdpc}$ & Income per capita & & $\begin{array}{c}0.102811^{* *} \\
(0.047525)\end{array}$ \\
\hline $\operatorname{lnpop}$ & Population & & $\begin{array}{c}0.7935079 * * * \\
(0.095940)\end{array}$ \\
\hline $\operatorname{lncrp}(-1)$ & Lag rice consumption & & $\begin{array}{c}0.016094^{* * *} \\
(0.006390)\end{array}$ \\
\hline $\mathrm{R}^{2}$ & & 0.968437 & 0.846711 \\
\hline $\operatorname{Adj}-R^{2}$ & & 0.955441 & 0.804130 \\
\hline F-stat & & 74.51559 & 19.88502 \\
\hline Prob(f-stat) & & 0.000000 & 0.000001 \\
\hline
\end{tabular}
Source: Authors calculation

In Table 7, from the model estimation results show that statistically show that if the factor of the number of labor increased $1 \%$, then in a year can encourage rice production increased by $0,116 \%$. In Indonesia, labor is a major factor in increasing rice production in rural areas, as most of the livelihoods of Indonesians are farmers. On the other side, the wage factor is a major factor in improving the productivity of farmers, in other words, if wages increase by $1 \%$, it will encourage farmers' productivity to encourage rice production to increase by $0.615 \%$ in a year. It's in line with the study Bagamba, Burger, \& Kuyvenhoven (2007); Edriss, Tchale, \& Wobst (2004); Llanto
(2012).

In addition, the wetland area is one of the factors driving rice production in Indonesia, from the regression estimation results indicating that if the width of rice field area increased by 1 hectare, it will encourage rice production to increase by $0.237 \%$ in a year. It is also supported by soil conditions in Indonesia, which mostly have alluvium soils that result from erosion deposited in the lowlands to be an excellent support factor for rice crops. Furthermore, the factor of urban population becomes one of the factors that can influence rice production (Bren d'Amour et al., 2016; Satterthwaite et al., 2010), statistically, if 
urban population increase by $1 \%$, it will directly decrease rice production by $0,670 \%$ in a year. The phenomenon that occurred in the last few decades, the number of villagers increasingly decreased, meaning that the process of urbanization that occurred in Indonesia increasingly significant, there are two factors causing the urbanization process among other: economic and non-economic factors (Turok \& McGranahan, 2013). Economic factors, among others: (1) limited resources such as agricultural land, and low wage rates in the village. While non-economic factors, among others: (1) social factors; (2) physical factors such as climate and natural disasters; (3) demographic factors; (4) cultural factors; and (5) infrastructure factors such as transportation facilities, education systems, and telecommunications (Turok \& McGranahan, 2013).

On the other side, our findings show that statistically that technology usage has no effect on rice production significantly. It's means that the use of agricultural technology in Indonesia is still low, the farmers in Indonesia still use traditional technology, in addition, the farmers in Indonesia are mostly able to cultivate rice only twice per year, because of inadequate irrigation systems and poor water management. Even though, were previously able to plant paddy three times per year. The rice production model in the study also enter the rice price factor, and the results show that price developments have a significant effect on rice production in Indonesia, statistically indicating that if the price of rice increases by $1 \%$, it will increase rice production by $0.101 \%$ in a year. Fluctuations in rice prices can be caused by many factors such as rice consumption, rice stock, and population (Reyes et al., 2009; Rosegrant \& Sulser, 2002).

\subsection{Analysis of rice consumption model}

In the rice consumption model, the estimation results indicated that rice consumption is influenced by human capital, per capita income, population and consumption of the previous year significantly. However, on the other side, the rice price does not really affect rice consumption in Indonesia, this is understandable due to the supply side, the availability of rice stock, will not change rice price significantly, hence not too much impact to changes of rice consumption. As stated from the results of the study by Nuryanti (2005) which states that rice prices are more affected by rice supply.

Statistically, the human capital has a negative effect on rice consumption, with a coefficient of -0.762 , meaning that if human capital increases one level, it will decrease rice consumption by $0.762 \%$ in a year (Table 7 ). It also means that the higher the education level of a person, the individual will reduce his rice consumption and switch to other food consumption choices. Along with the current technological advances, the Indonesian government also encourages the diversification of food, which is intended so that people are not fixated on one type of staple food and driven to consume other foodstuffs as a substitute for the staple food that has been consumed. Indonesia has a variety of agricultural products that can actually be used as staple foods such as breadfruit, sweet potato, taro, etc. That can be a major supporting factor of food diversification. Diversification of food is one way to achieve self-sufficiency in rice by reducing rice consumption so that total consumption not exceeding production.

Meanwhile, the per capita income indicated a positive sign, per capita income has a coefficient value of 0.102 , which means that if per capita income increase by $1 \%$, then rice consumption will increase by $0.102 \%$ (Table 7 ). In microeconomic theory, the relationship that is justified because when the income increases then consumption will also increase (Mas-Colell, Whinston, \& Green, 1995). Likewise with the variable population, the results of the model's estimation indicated for the population on rice consumption also has a positive sign, which is shown from the coefficient value of 0.793 , which means that if the population increases by $1 \%$, then the rice consumption will increase $0.793 \%$ in a year. In many studies, 
changes in population have always been one of the factors that will influence changes in other economic variables, such as in microeconomic theory, changes in the population become one of the factors that will affect the demand quantity (Mas-Colell, Whinston, \& Green, 1995). In addition, from the estimated result indicated also that the previous year's rice consumption also affected the current rice consumption, which is shown from the coefficient value of 0.016 (Table 7 ), meaning that when the previous year's rice consumption increased by $1 \%$, it will increase the current rice consumption by $0.016 \%$ the results of the study are in line with the study by Malian et al. (2004).

\section{Conclusions}

The aims of this study are to estimate rice production and consumption in Indonesia and determine the main factors that influence it by using multiple linear regression models with OLS estimators. This study uses 24 years data, the data obtained from the Central Bureau of Statistics "Statistics Indonesia" in various editions. The results of this study indicate that rice production is influenced by human capital, labor, wages, wetland, urban populations, and the price of rice significantly, and coefficient sign shows a positive relationship, whereas technology has no significant effect. From these conclusions the implication in this study is that the long-term balance of the system leading to equilibrium and stable (convergence), implicitly indicates that it does not interfere with market stability, supply and demand of rice are relatively stable over the long term, safe to implement. On the contrary, the technology used is assumed to be very low, it is an important note for the government in making the right program policies such as the development of irrigation systems and better water management.

Based on the estimation of rice consumption model shows that human capital, income per capita, population and the previous year consumption significantly. However, on the other side, the rice price has no effect the rice consumption in Indonesia. Statistically, the coefficient sign shows a negative sign for human capital, whereas the per capita income, population, and the previous year consumption showed a positive sign. The implication of this study is that the policy of output price (rice) does not cause disruption of market stability, and demand for rice is relatively stable, meaning that rice price policy is quite safe to be implemented. The study using multiple regression equation models for the rice supply and demand system in Indonesia has been able to evaluate long-term effects. That is, this method can be implemented for similar studies on agricultural commodities and non-agricultural commodities.

\section{Acknowledgment}

This study is a part of the grand project "Hibah Penelitian Unggulan Kompetitif." We thank Universitas Sriwijaya for financial support of this research through "Hibah Penelitian Unggulan Kompetitif 2017, contract Number: 988/UN9.3.1/PP/2017.

\section{References}

Antle, J. M. (1984). Human capital, infrastructure, and the productivity of Indian rice farmers. Journal of Development Economics, 14(1), 163-181. https://doi.org/10.1016/03043878(84)90048-8

Apostolidou, I., Kontogeorgos, A., Michailidis, A., \& Loizou, E. (2014). The Role of Agriculture in Economic Growth: A Comparison of Mediterranean and Northern Views in Europe. International Journal of Economic Sciences and Applied Research, 7(3), 81-102.

Azwardi, Bashir, A., Adam, M., \& Marwa, T. (2016). The effect of subsidy policy on food security of rice in Indonesia. International Journal of Applied Business and Economic Research, 14(13), 9009-9022.

Bagamba, F., Burger, K., \& Kuyvenhoven, A. (2007). Determinants of Smallholder Farmer Labour Allocation Decisions in Uganda. In 
Paper prepared for presentation at the 106th seminar of the EAAE, 25-27 October 2007 (pp. 1-22). Montpellier, France.

Barro, R. J., \& Lee, J. W. (2013). A new data set of educational attainment in the world. Journal of Development Economics (Vol. 104). https:// doi.org/10.1016/j.jdeveco.2012.10.001

Bordey, F. H. (2010). The Impacts of Research on Philippine Rice Production. In University of Illinois at Urbana-Champaign (pp. 1-137).

BPS. (2016). Statistical Yearbook of Indonesia in various editions. (BPS, Ed.). Jakarta: Badan Pusat Statistik.

Bren d'Amour, C., Reitsma, F., Baiocchi, G., Barthel, S., Güneralp, B., Erb, K.-H., ... Seto, K. C. (2016). Future urban land expansion and implications for global croplands. Proceedings of the National Academy of Sciences, 114(34), 8939-8944. https://doi. org/10.1073/pnas.1606036114

Chen, A. Z., Huffman, W. E., \& Rozelle, S. (2003). Technical Efficiency of Chinese Grain Production: A Stochastic Production Frontier Approach. In American Agricultural Economics Association Annual Meeting (pp. 1-29). Montreal, Canada.

Clapp, J. (2017). Food self-sufficiency: Making sense of it, and when it makes sense. Food Policy, 66, 88-96. https://doi.org/10.1016/j. foodpol.2016.12.001

Clarete, R. L., Adriano, L., \& Esteban, A. (2013). Rice trade and price volatility: Implications on ASEAN and global food security. $A D B$ Economics Working Paper Series, 368(368), 1-35.

Dawe, D. (2000). The contribution of rice research to poverty alleviation. Studies in Plant Science (Vol. 7). Elsevier Masson SAS. https://doi. org/10.1016/S0928-3420(00)80003-8

Dickey, D. A., \& Fuller, W. A. (1979). Distribution of the Estimators for Autoregressive Time
Series With a Unit Root. Journal of the American Statistical Association, 74(366a), 427-431.

Edriss, A., Tchale, H., \& Wobst, P. (2004). The impact of labour market liberalization on maize productivity and rural poverty in Malawi. In Policy Analysis for Sustainable Agricultural Development (PASAD) (pp. 1-19). Germany: University of Bonn. Retrieved from http://www.pasad.uni-bonn. de/Edriss_et_al_The_Impact.pdf

Ekou, N. (2015). The Effect of Primary Education on Maize Productivity in Ivory Coast. European Scientific Journal, 11(25), 203217.

Fairhurst, T. H., \& Dobermann, a. (2002). Rice in the Global Food Supply. Better Crops International, 16(May), 8-11.

Fakayode, S. B., Omotesho, O. A., \& Omoniwa, A. E. (2010). Economic Analysis of Rice Consumption Patterns in Nigeria. J. Agr. Sci. Tech., 12(2), 135-143.

FAO. (2009). The State of Food and Agriculture. Livestock in the Balance. https://doi.org/ ISBN: 978-92-5-107671-2 I

Felipe, J., \& Adams, G. F. (2005). A Theory of Production. The estimation of the CobbDouglas function: a retrospective view. Eastern Economic Journal, 31(3), 427-445. https://doi.org/-

FRED. (2018). Index of Human Capital per Person for Indonesia. California: Federal Reserve Bank of St. Louis. Retrieved from https://fred. stlouisfed.org/series/HCIYISIDA066NRUG

Grochowska, R., \& Kosior, K. (2013). Agricultural policies in the context of regional and global food security concerns - the case of the Asian region. In Institute of Agricultural and Food Economics (pp. 25-33).

Gujarati, D. N. (2004). Basic Econometrics. United States: The McGraw-Hill Companies. 
Huffman, W. E. (2000). Human Capital, Education, and Agriculture. In International Congress of Agricultural Economics (Vol. 24, pp. 333-381). https://doi.org/10.1016/S15740072(01)10010-1

Huffman, W. E., \& Orazem, P. F. (2007). Agriculture and Human Capital in Economic Growth: Farmers, Schooling and Nutrition. In R. Evenson \& P. Pingali (Eds.), Handbook of Agricultural Economics (Vol. 3, pp. 22812341). North Holland: Elsevier B.V. https:// doi.org/10.1016/S1574-0072(06)03043-X

Im, K. S., Pesaran, M. H., \& Shin, Y. (2005). Testing for seasonal unit roots in heterogeneous panels. Journal of Econometrics, 115(1), 53-74. https://doi.org/10.1016/j. econlet.2004.06.018

Inoue, S., Okae, T., \& Akashi, K. (2015). Rice Policy Trends in Southeast Asian Countries: Thailand, Vietnam and Indonesia. PRIMAFF Review, 66(7), 4-5.

Jha, S., Kubo, K., \& Ramaswami, B. (2016). International trade and risk sharing in the global rice market: The impact of foreign and domestic supply shocks. Asian Development Review, 33(1), 162-182. https:// doi.org/10.1162/ADEV_a_00064

Kea, S., Li, H., \& Pich, L. (2016). Technical Efficiency and Its Determinants of Rice Production in Cambodia. Economies, 4(4), 1-22. https://doi.org/10.3390/ economies 4040022

Koirala, K. H., Mishra, A. K., \& Mohanty, S. (2013). Determinants of Rice Productivity and Technical Efficiency in the Philippines. Southern Agricultural Economics Association (SAEA) Annual Meeting, (October 2015), 1-16. https://doi.org/10.13140/2.1.3275.1360

Levin, A., Lin, C. F., \& Chu, C. S. J. (2002). Unit root tests in panel data: Asymptotic and finite-sample properties. Journal of Econometrics, 108(1), 1-24. https://doi.
org/10.1016/S0304-4076(01)00098-7

Llanto, G. M. (2012). The Impact of Infrastructure on Agricultural Productivity. In Discussion Paper (pp. 469-486). Philippine Institute for Development Studies. Retrieved from http:// www.scopus.com/inward/record.url? eid=2s2.0-0028580356\&partnerID=tZOtx3y1

Malian, A. H., Sudi, M., \& Mewa, A. (2004). Faktor-faktor yang mempengaruhi Produksi, Konsumsi dan Harga Beras serta Inflasi. Bahan Makanan. Jurnal Agro Ekonomi, 22(2), 119-146.

Mas-Colell, A., Whinston, M. D., \& Green, J. R. (1995). Microeconomic theory. New York: Oxford University Press. https://doi. org/10.2307/135312

Micheal, R. T. (1972). Human Capital and Consumption: The Theoretical Framework. In The effect of education on efficiency in Consumption (Vol. Chapter I, pp. 7-13). Retrieved from www.nber.org/books/mich721\%5Cnwww.nber.org/chapters/c3514

Milovanovic, V., \& Smutka, L. (2017). Asian countries in the global rice market. Acta Universitatis Agriculturae et Silviculturae Mendelianae Brunensis, 65(2), 679-688. https://doi.org/10.11118/ actaun201765020679

Nuryanti, S. (2005). Analisa Keseimbangan Sistem Penawaran dan Permintaan Beras di Indonesia. Jurnal Agro Ekonomi, 23(1), 71-81.

Phillips, P. C. B., \& Perron, P. (1988). Testing for a unit root in time series regression. Biometrika, 75(2), 335-346.

Reyes, C. M., Sobrevinas, A. B., Bancolita, J., \& Jesus, J. De. (2009). Analysis of the Impact of Changes in the Prices of Rice and Fuel on Poverty in the Philippines. In Discussion Paper (pp. 1-73). Philippine Institute for Development Studies. 
Rosegrant, M. W., \& Sulser, T. (2002). Rice Price Crisis: Causes, Impacts, and Solutions. Asian Journal of Agriculture and Development, $7(2), 1-15$.

Satterthwaite, D., McGranahan, G., \& Tacoli, C. (2010). Urbanization and its implications for food and farming. Philosophical Transactions of the Royal Society B: Biological Sciences, 365(1554), 2809-2820. https://doi.org/10.1098/rstb.2010.0136

Shaikh, S. A., \& Ahmed, M. (2016). Determinants of Rice Productivity: An Analysis of Jaffarabad District -Balochistan (Pakistan). European Scientific Journal, 12(13), 41-50. https://doi.org/10.19044/esj.2016.v12n13p41

Tiffin, R., \& Irz, X. (2006). Is agriculture the engine of growth? Agricultural Economics, $35,79-89$.

Timmer, C. P. (2013). Food Security in Asia and the Pacific: The Rapidly Changing Role of Rice. Asia \& the Pacific Policy Studies, 1(1), 73-90. Retrieved from http://doi. wiley.com/10.1002/app5.6\%5Cnpapers2:// publication/doi/10.1002/app5.6

Turok, I., \& McGranahan, G. (2013). Urbanization and economic growth: The arguments and evidence for Africa and Asia. Environment and Urbanization, 25(2), 465-482. https:// doi.org/10.1177/0956247813490908

Wardis, G. (2014). Food Security Systems in Indonesia: Challenges and Implications to Food Security in Maluku. Occasional Paper, 12(54), 35-45.

Wohlgenant, M. K., \& Hahn, W. F. (1982). Dynamic Adjustment in Monthly Consumer Demands for Meats. American Journal of Agricultural Economics, 64(3), 553-557. https://doi.org/10.2307/1240649 